Faculdade

de Ciências Econômicas UFRGS
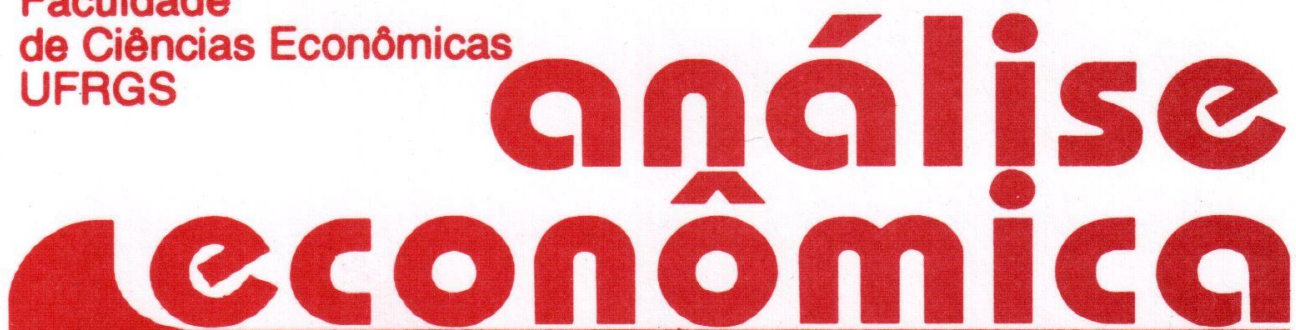

- SIDERURGIA E O PARADIGMA TECNOLÓGICO

Angela Maria Morandi

- ESTIMATING PRIVATE DEMANDS FOR PUBLIC GOODS

Eduardo Pontual Ribeiro

- KEYNES E A ATUALIDADE DA TEORIA KEYNESIANA

Fernando Ferrari Filho

- IMPRODUTIVIDADE DE UM CONCEITO DE PRODUÇÃO Raul Cristóvão dos Santos

- A NEGAÇÃo dA INEFICÁCIA DA POLÍTICA MONETÁRIA João Sicsú

- DESREgulamentAÇÃo, globa LIZAÇÃo E A CADEIA DO TRIGO Lena Lavinas

Manoel Magina

- ALUGUÉIS RESIDENCIAIS EM PORTO ALEGRE

Marco Aurélio Stumpf González

- POLICY INTERVENTION AND THE TRADE-OFF BETWEEN GROWTH AND DISTRIBUTION OF INCOME Joanílio Rodolpho Teixeira Jorge Thompson Araujo

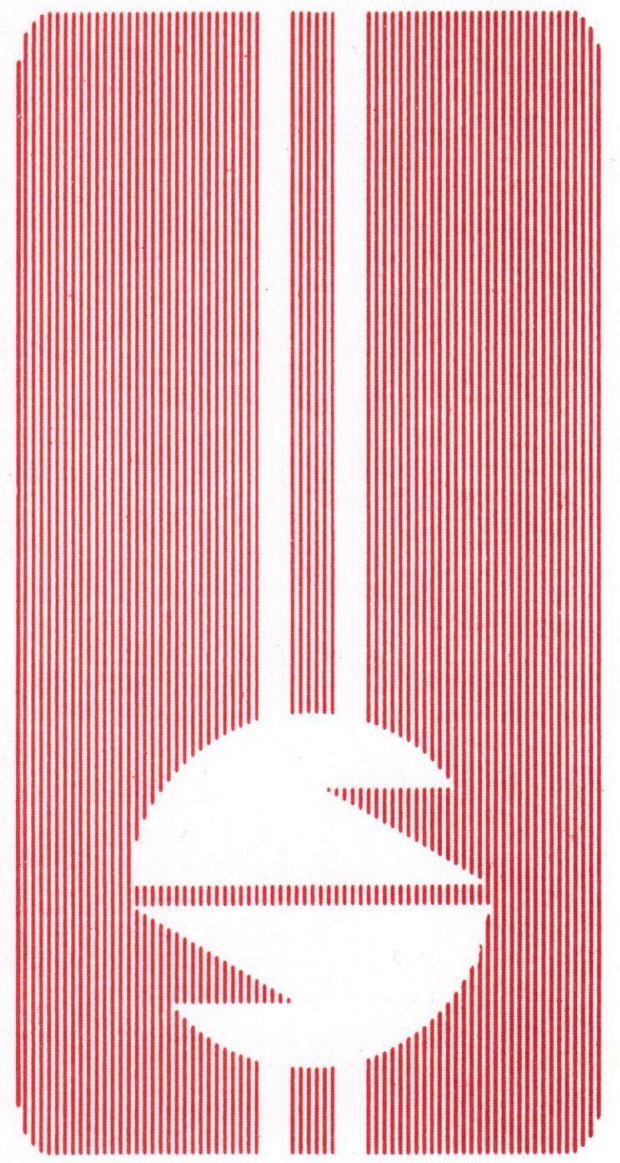


UNIVERSIDADE FEDERAL DO RIO GRANDE DO SUL

Reitora: Prof ${ }^{a}$. Wrana Maria Panizzi

FACULDADE DE CIENNCIAS ECONÓMICAS

Diretora: Prof ${ }^{\mathrm{a}}$. Otilia Beatriz Kroeff Carrion

CENTRO DE ESTUDOS E PEQUISAS ECONÔMICAS

Diretor. Prof. Fernando Ferrari Filho

DEPARTAMENTO DE CIÊNCIAS ECONÓMICAS

Chefe: Prof. Gentil Corazza

CURSO DE PÓS-GRADUAÇÃO EM ECONOMIA

Coordenador. Prof. Marcelo Savino Portugal

CURSO DE PÓS-GRADUAÇÃO EM ECONOMIA RURAL

Coordenador: Prof. Carlos Guilherme A. Mielitz Netto

CONSELHO EDITORIAL: Achyles B. Costa, Aray M. Feldens, Carlos A. Crusius, Carlos G. A. Mielitz Netto, Eduardo A. Maldonado Filho, Eduardo P. Ribeiro, Eugênio Lagemann, Fernando Ferrari Filho, Gentil Corazza, Marcelo S. Portugal, Nali J. Souza, Otília B. K. Carrion, Paulo A. Spohr, Paulo D. Waquil, Pedro C. D. Fonseca, Roberto C. Moraes, Ronald Otto Hillbrecht, Stefano Florissi, Eleutério F. S. Prado (USP), Fernando H. Barbosa (FGV/RJ), Gustavo Franco (PUC/RJ), João R. Sanson (UFSC), Joaquim P. Andrade (UnB), Juan H. Moldau (USP), Paul Davidson (Univ. of Tennessee), Werner Baer (Univ. of Illinois).

COMISSÃO EDITORIAL: Eduardo Augusto Maldonado Filho, Fernando Ferrari Filho, Gentil Corazza, Paulo Dabdab Waquil, Marcelo Savino Portugal, Roberto Camps Moraes.

EDITOR: Nali de Jesus de Souza

SECRETARIA: Cláudia Porto Silveira, Sandra Mascarello e Fábio Régis Sparremberger. Revisão de textos: Vanete Ricacheski.

FUNDADOR: Prof. Antônio Carlos Santos Rosa

Os materiais publicados na revista Análise Económica são da exclusiva responsabilidade dos autores. É permitida a reprodução total ou parcial dos trabalhos, desde que seja citada a fonte. Aceita-se permuta com revistas congêneres. Aceitam-se, também, livros para divulgação, elaboração de resenhas e recensões. Toda correspondência, material para publicação (vide normas na terceira capa), assinaturas e permutas devem ser dirigidos ao seguinte destinatário:

PROF. NALI DE JESUS DE SOUZA

Revista Análise Econômica - Av. João Pessoa, 52

CEP 90040-000 PORTO ALEGRE - RS, BRASIL

Telefones: (051) 316-3348 e 316-3440 - Fax: (051) 316-3990

nali@vortex.ufrgs.br 


\title{
ESTIMATING PRIVATE DEMANDS FOR PUBLIC GOODS: A SURVEY
}

\section{Eduardo Pontual Ribeiro}

\begin{abstract}
The main purpose of this paper is to present a methodology for the empirical study of individual preferences for public goods. We survey the literature annotating the main critiques to the now seminal paper of Bergstrom and Goodman(1973) and present some suggestions on the direction of future research.
\end{abstract}

AEA Code: 010 Key words: Demands for public goods; median voter

\section{RESUMO}

Este artigo propõe uma metodologia para estudos empíricos das preferências individuais para bens públicos. Através de uma revisão crítica da literatura, tomando como base o seminal artigo de Bergstrom e Goodman (1973), apontamos os componentes mínimo para estudos empíricos nessa área.

Cód. AEA 010 Palavras-chave demanda por bens públicos; eleitor mediano.

\section{INTRODUCTION}

In order to built sound policy, the public official must recognize the preferences of individuals. In the case of private goods, one need to obtain output, prices and income observations and estimate a utility maximization consistent demand function. On the other hand, for the case of public goods, one needs to use a more sophisticated mechanism of preference

Professor da Universidade Federal de Roraima e do Curso de Pós-Graduação em Economia da UFRGS. Porto Alegre, RS, 90040, Brazil - E-mail: eribeiro@vortex.ufrgs.br.

\begin{tabular}{|l|l|l|l|l|}
\hline ANÁLISE ECONÔMICA & ANO 15 & N. 28 & Setem bro/97 & p. 35 - 43 \\
\hline
\end{tabular}


revelation than prices. This is the most important message of Samuelson (1954).

For the case of public goods, the political system plays a key role in determining the aggregation of individual preferences. There are two approaches to the output decisions in democracies with majority voting. First, given the result that if preferences are single peaked over a sigledimensional issue, the voter who demands the median quantity of public good cannot lose, then the only relevant public good preferences are those of the median voter. This is the famous Median Voter Theorem. ${ }^{1}$ Second, if public, officials have some degree of agenda control (or any assumption of the median voter theorem does not hold), then there is some other mechanism for preference aggregation at work. The extreme example would be the budget-maximizing bureaucrat model of Niskanen (1971), while other possibilities may be an income aggregated mechanism i.e., politicians have 'better ears' for the preferences of rich individuals or an aggregation based on demographic characteristics.

The seminal paper on the empirical study of individual preferences for public goods is the work of Bergstrom and Goodman (1973), BG hereafter. There they study expenditure decisions of 826 municipalities, located in US states, using the median voter framework. In this paper, we shall review the authors' work, using it as a base to present guidelines to future studies, drawing on later works that criticize $B G$ and recent theoretical developments.

\section{THE BERGSTOM AND GOODMAN METHODOLOGY}

In this section we shall review BG's methodology, listing the assumptions used and then criticizing each, so to build a methodology.

Let there be $j=1, \ldots, J$ municipalities, where $i=1, \ldots I$ consumers live. Let $X_{i}$ be the a Hicksian composite numeraire private good and $Z_{i}^{*}$ the actual quantity available of public good to the individual $i$. Let $n$ be the number of individuals in a community. The relationship between the amount of public good actually perceived by the agent and the output provided by the government, $Z$, is determined by $Z_{i}^{*}=z(n, Z)$. Thus, the individual $B G$ assumptions are:

1. Public Goods are measured in such a way that each municipality $j$ supplies $Z$ at constant unit cost $q_{j}$.

\footnotetext{
${ }^{1}$ See Mueller, 1989 for a complete exposition of the Median Voter Theorem.

2 Some of the criticisms listed here have been pointed out by Romer and Rosenthal (1979), RR hereafter, and Todó-Rovira (1987) among others
} 
2. Each consumer pays a fraction $\tau_{i}$ of the total cost; further, $\tau_{i}$ does not varies with $Z$.

3. Consumers have perfect information on its tax price $\tau_{i} q_{i}$; this is the 'price' of the public good.

4. The quantity supplied is the median quantity demanded.

5. The median quantity demanded is demanded by the median individual dual income. Further, the median income agent lives in the median value property and the property is its only property holding.

6. The quantity demanded is a monotonic function of income, across all $j$ and on the whole range of $Y_{i}$, income.

7. Individuals perceive $Z_{i}^{*}=n^{-\gamma} Z$ of the public good (congestion function specification).

8. Prices of private and public goods are the same across $j$.

9. Individuals believe that new taxes will not be disproportionally assigned to firms. Further, the taxes paid by commercial and industrial property is borne by individuals living outside $j$; or their number is very small.

Further, BG assume that the elasticity of substitution between public and private goods is zero. Stiglitz (1974) has shown that if there are private substitutes, single peakedness is destroyed, as RR note. In terms of the estimation, the omission of a non-zero elasticity of substitution will lead to bias in the estimates.

Let us now comment on the above assumptions. As we shall see, most are compromises so to avoid too complicated estimation orto meet the availability of data. Unfortunately these compromises may be harmful.

Assumption 1 is necessary in order to abstract the supply side on the provision of public goods. The assumption leads to a horizontal supply of public goods. In addition, by assuming a constant unit cost the "tax price" is an exogenous variable and no bias in generated by estimating a demand function only. Implicitly, as BG state in their footnote 2, they assume that municipalities have (identical) homothetical production functions and face horizontal input supply curves. The 'identical' is necessary when prices change across $j$. It seems that assumption 1 was necessary so that one could avoid dealing with the production side of public goods.

While assuming that the consumer i's tax share does not change with the size of municipal expenditures is not significant, given that any change in constant costs are taken up by $q_{j}$, the authors forget that the tax share does depend upon $n$, the number of individuals in the community. To see why, note that the tax share is such that, within a community, public goods production costs are covered: 


$$
\sum_{i=1}^{1} \tau_{i} q_{i} Z=q Z
$$

Thus if $I$ increases, it must be the case that at least one of the tax shares $\tau_{i}$ decreases. This will be relevant, if we are to assume mobility of agents. $^{3}$

While the third assumption is standard of demand studies under certainty, BG provide a theorem (in their appendix) that shows that under certain conditions, the errors in perception of the tax price are insignificant to the estimation process. Of course the violation of this assumption will bias estimates, but this is a problem of demand estimation, not of their methodology.

The fourth assumption is the Median Voter Theorem, MVT hereafter. Obviously this assumption will hold only if the Theorem holds. This is a significant weakness of their methodology. Their model cannot test the MVT against competing models of individual preferences aggregation, it just takes it as a working assumption. But the MVT will fail if:

1. Individuals do not have single peaked preferences over a one dimensional issue and/or there is a multidimensional issue. ${ }^{4}$

2. There is incomplete turn-over (Munley, 1984).

3. Individuals cannot vote on the whole range of output level. ${ }^{5}$

4. There is some agenda control from the part of the bureaucrats or legislative.

5. Expenditure decisions are not made via referenda (see RR).

6. There are substitutes for public goods (Stiglitz, 1974).

We see there is an important institutional framework needed so that the MVT may be at work. GB do not present any information on whether the above conditions are met. In fact, $R R$ indicate that 'most of the municipal expenditure decisions analyzed by $G B$ are in fact made by representative legislatures'(p.159). Further, Munley (1984) developing a methodology by Holocombe(1980), shows that the reversion level, when a referendum proposal is defeated, and the number of referenda are significant to determine whether the expenditure level is the median one. Finally, Romer et al. (1993) show that the existence of matching grants are significant on determining the median desired amount of public good.

\footnotetext{
${ }^{3}$ And of course the possibility of some kind of Tiebout equilibrium. Allowing for the Tiebout hypothesis will destroy the assumption of proportionality of income distributions across communities. We shall return to this below.

${ }^{4}$ See Mueller (1989), for the conditions on multidimensional issues

5 in other words, there is only a limited number of referenda and/or agents can only vote yes or no for a given quantity. See RR.
} 
Assumptions 1-4 determines that the community is in Bowen Equilibrium. This means that the amount of Public Good provided is efficient; the public good supply is Pareto Optimal. Unfortunately, as Bergstrom (1979) shows, the Bowen Equilibrium will hold if and only if the mean of the marginal rates of substitution (MRS) between the public and private composite good is equal to these rate, or in the following cases:

1. The distribution of the MRS among individuals given the amount of public goods and the tax rate is symmetric.

2. There is transferable utility.

3. Agents have different (identical) preferences on a log-linear utility function and identical (different) wealth(s).

4. Proportional wealth tax and log linear utility functions.

5. Or the income distribution is proportional in the BG sense.

These are indeed quite restrictive assumptions. In fact, Goldstein and Pauly (1981) show that if some kind of Tiebout mechanism is at work, then the income distribution across communities will not be proportional. The main implication of the failure of the Bowen Equilibrium hypothesis is that each municipality observations will not be as an observation on the demand curve for the median voter.

But probably the main weakness of the BG methodology is the identification of the median voter, assumption 5. Even if the MVT holds the median voter will be the one that has median income if and only if there are differences in tastes but income distributions are proportional across communities (BG's theorem 1) or if in each municipality individuals have monotonic demands when income changes everywhere over the range of public good output, assumption 6 . This implies that agents have constant price (tax) and income elasticities. Todó-Rovira (1987) is keen to show that this is an unduly restrictive assumption and that it has significant consequences for the parameter estimation. RR criticize this assumption on the combined effects of income and family size, the latter not even considered by $B G$.

Todó-Rovira $(1987,1991)$ extend the BG model so that the median voter theorem is tested. While he claims that his methodology tests whether the MVT holds, it tests whether the median-voter is the one that has the median income or is in a different fractile of the income distribution, i.e., the aggregation process is income weighted. His methodology is relevant to avoid the fractile fallacy, in the sense of $R R .^{6}$

The fractile fallacy means that the model cannot distinguish whether the

\footnotetext{
${ }^{6}$ While in his theoretical presentation he entertains the idea that the median voter is the one with mean income or a function of the taxes paid, his empirical model is able to test only the income-weighted aggregation assumption.
} 
mean income or median or any other fractile of income is pivotal to determine the amount of public goods demanded. The regression model only indicates that there is a significant correlation between output and the median characteristics of the municipality. Whether this median characteristics are in fact those of the voter that demands the median output, it cannot be verified.

The second part of assumption 5 is needed so that the authors can asses the tax share of the median income individual, that is assumed to be the median voter. One sees that the constant income and price elasticities are a compromise in order to make the estimation and data requirement problems manageable. While this may be a compelling reason for such assumptions, it menaces the generality of conclusions and risk the accuracy of the estimated parameters. Another of such 'convenience' assumptions is assumption 9 . If that was not the case, then the true tax price will depend upon the incidence of taxes and in the case the median voter owns commercial or industrial property his/hers tax share will be underestimated.

Assumption 7 deals with the congestion (or crowding) properties of the public good. The rationale behind this assumption is that the publicly provided good may not be a pure public good. Thus, as more individuals share the good, more of this good should be produced so to keep the level perceived by each agent constant. In the case of the functional form chosen by $B G, R R$ notes that the range of the crowding parameter is $0 \leq \gamma \leq 1$, determining a pure public and a pure private good, respectively. BG do not determine the upper bound. If the parameter is greater than one then one is faced with the idea that the amount of the good perceived by each agent is less than the amount in the case the good were a private one. This uncomfortable result leads RR to conclude that, due to misspecification of the demand function, the parameter is picking up both economics of consumption and diseconomies in production as population size increases. Recall that the model assumes that the public good is produced at constant costs, so if diseconomies in production are present, they will bias the the crowding parameter.

Regardless of the above criticisms, Edwards (1990) develops a flexible functional form so to allow for both decreasing (BG model) and increasing marginal congestion and variable congestion rates across the population range. His conclusions, based on a model that follows BG very closely, but with a different data set, are that while the constant crowding assumption is not warranted, there is evidence of diminishing marginal congestion. Thus one should use his flexible form specification of the congestion function in future empirical studies, even though his conclusions suffer from the same problems as BG does.

Finally, assumption 8 is quite important. The first implication is that 
different public/private good ratios across communities will render the dependent variable as a biased measure of output. Second, and more important is that, if one follows BG's footnote 7 , it is clear that the estimation was constrained under the assumption that the price elasticity $\varepsilon$ was equal to unity, so that the estimation is invariant to different price ratios across communities. And most of the estimated elasticity's are indeed close to one. The seriousness of the constant price ratio is recognized in Bergstrom et al (1982). It seems that in the latter work the data on prices was available to the authors.

Before we draw the conclusions of this survey, summarizing the guidelines for future empirical studies of the demand for public goods, I will comment on two other works, not summarized in RR. Bergstrom et al (1982) suggest the use of micro-data, from surveys, to study the demand for public goods, given the superior fit of such data when compared to aggregate data. This also circumvents the assumption that the median voter is the one with the median income. In fact it allows for the test of this assumption.

The second study, by Murdoch et al (1991) claims to test the MVT against an oligarchy choice model of public good output determination. The testing variable is whether the amount of military expenditures in NATO countries is a function of the median income of that country (so the MVT holds) or whether is not a function of income (so the oligarchy model holds). If both hypothesis are rejected "some unspecified model like voter pressure group" holds (p.628). Again, the study fall into the fractile fallacy. Second, there is no guidance if whether individuals in the NATO countries actually vote on military expenditures by referenda, or the expenditure decision is a part of the total budget for the fiscal year. In the latter case, it is quite unlikely that voters have single-peaked preferences. And in the former, representative voting produces significant noise, as $R R$ indicate. Not surprisingly, the conclusions are not strong for any of the hypothesis considered.

\section{CONCLUDING COMMENTS}

In this paper we have critically assessed empirical studies of individual demands for public goods. We used as base for our study the now 'canonical' [Romer et al (ibid)] model of Bergtrom and Goodman (1973), which is based on the median voter theorem and the assumption that the median voter is the one that has the median income. The suggestions for empirical studies are clear.

First and foremost the researcher should identify the institutional setting where expenditure decisions take place. The voting procedure, the reversion level, the opportunity for agenda control by bureaucrats, the 
presence of matching grants, are among the variables that determine the institutional framework Second, micro-data should be preferred with respect to aggregate data. ${ }^{7}$ Third, the assumption of constant unit costs should be avoided. It has been suggested that the crowding parameter of the demand function may be significantly biased because of such assumption. Of course this implies that data on the production of public goods must be available. Fourth, one should use a flexible congestion function specification, following Edwards (1991). Fifth, the demand function should be flexible enough so to allow for non-zero elasticity of substitution between private and public goods and non-constant income and price elasticities. Last, one should make the assumption that the median voter has the median income a working assumption, following Todó-Rovira (1987).

In terms of theoretical models one should consider strategic behavior by both suppliers and demanders of public goods. Holocombe (1980) is a good example of such conflict. It would be interesting also to fit a model where the supply side is determined by a Niskanen-type bureaucrat ${ }^{8}$ and the demand side is based on some (unknown) aggregation of individual preferences. Imperfect information on both sides ${ }^{9}$ may also be important in determining the functional form on empirical studies of public goods preferences.

We realize that the above suggestions impose high costs in terms of required data. But we claim, based on different literature results, that any compromise on the above suggestions may generate significant bias in the estimates, endangering the conclusions obtained.

\section{REFERENCES}

BANKS, JS Monopoly Agenda Control and Asymmetric Information. Quarterly Journal of Economics, v 105, p 115-126, 1990

BERGSTROM, Ted. When does majority rule supply public goods efficiently? Scandinavian Journal of Economics, $v$. 81, p. 217-226, 1979

BERGSTROM Ted and GOODMAN, Richard. Private demands for public goods. American Economic Review, v.63, p. 280-296, 1973.

BERGSTROM, Ted, RUBINFELD, Daniel and SHAPIRO, Paul. Micro-based estimates of demand functions for local school expenditures Econometrica, v. 50, p. 1183-1205, 1982.

CHAN, Kim S Y A behavioral model of bureaucracy. Southern Economic Journal, v. 45, $p$

${ }^{7}$ For details of the methodology in such case, see Bergstom et al, 1982.

${ }^{8}$ For an overview on the budget-maximizing bureaucrat, see Mueller (1989, Ch. 14).

9 Banks, 1990 and Morton, 1988, study information uncertainty on the demand and supply sides respectively.

${ }_{10}$ Chan, 1979, shows that with uninformed and unconcerned voters, bureaucracy may expand public budget beyond the optimal level. 
$1188-1194,1979$

EDWARDS, John Congestion function specification and the 'publicness' of local public goods. Journal of Urban Economics, v.27, p. 80-96, 1990.

GOLDSTEIN, G and PAULY, M. Tiebout bias on the demand for public goods Journal of Public Economics, v.16, p. 131-143, 1981.

HOLCOMBE, Robert. An empirical test of the median voter model Economic Inquiry, $\vee .18, p$ 260-74, 1980.

MORTON, $R$. Strategic voting in repeated referenda. Social Choice and Welfare, v. 5, p. 45$68,1988$.

MURDOCH, John, SANDLER, Todd and HANSEN, Lars. An econometric technique for comparing median voter and oligarchy choice models of collective action the case of the NATO alliance. Review of Economics and Statistics, $v$ 73, p. 624-31.

MUELLER, Dennis. Public Choice II. New York: Cambridge University Press, 1989

MUNLEY, Victor. Has the median voter found a ballot box he can control? Economic Inquiry, v. 22, p. 323-336, 1984.

ROMER, Thomas and ROSENTHAL, Henry. The elusive median voter. Journal of Public Economics, v.12, p.143-170, 1979

ROMER, Thomas, ROSENTHAL, Henry and MUNLEY, Victor Economic incentives and political institutions. spending and voting in school budget referenda. Journal of Public Economics, v.49, p. 1-33, 1992.

SAMUELSON, Paul. A pure theory of public expenditure Review of Economics and Statistics, v 36, p. 387-389, 1954

STIGLITZ, Joseph. The demand for education in public and private school systems. Joumal of Public Economics, v.3, p 349-185, 1974

TODO-ROVIRA, Antonio. The provision of local public goods theory and empirical evidence. Tese de doutorado inédita, University of California, San Diego, 1987.

TODÓ-ROVIRA, Antonio. Empirical analysis of the provision of local public goods: an alternative to the median voter model. Public Finance, v 49, p. 490-511, 1991. 